Article

\title{
A Nice Tailwind: The EU's Goal Achievement at the IMO Initial Strategy
}

\author{
Joseph Earsom * and Tom Delreux \\ Institute of Political Science Louvain-Europe, University of Louvain (UCLouvain), Belgium; \\ E-Mails: joseph.earsom@uclouvain.be (J.E.), tom.delreux@uclouvain.be (T.D.) \\ * Corresponding author
}

Submitted: 25 March 2021 | Accepted: 4 July 2021 | Published: 30 September 2021

\begin{abstract}
In April 2018, the International Maritime Organization (IMO) reached agreement on its Initial Strategy to reduce greenhouse gas emissions from international shipping. The Initial Strategy was a success for the EU, as it achieved its long-term objective of reaching an international agreement on greening shipping. However, several factors call into question whether the "success" was the result of the role played by the EU. Using process-tracing, we provide insight into the factors and the mechanism that led the EU to achieve its objective with the Initial Strategy. The article finds that the EU's goal achievement was the result of a mechanism triggered by (1) its overarching objective for action in the IMO on emissions in international shipping; (2) an entrepreneurial coalition partner; and (3) mounting momentum for action in the IMO. While the EU, including through its member states, played an important role in the negotiations, it only did so relatively late in the process, building on the successful work of the Shipping High Ambition Coalition. Based on this case study, we note implications not only for the proposed aspects of the European Green Deal related to greenhouse gas emissions from shipping, but also our understanding of the EU as an international (climate) actor.
\end{abstract}

\section{Keywords}

climate negotiations; European Green Deal; European Union; maritime emissions

\section{Issue}

This article is part of the issue "Climate Governance and the European Green Deal in Turbulent Times" edited by Claire Dupont (Ghent University, Belgium) and Diarmuid Torney (Dublin City University, Ireland).

(C) 2021 by the authors; licensee Cogitatio (Lisbon, Portugal). This article is licensed under a Creative Commons Attribution 4.0 International License (CC BY).

\section{Introduction}

As the urgency of the climate crisis has become increasingly apparent, various international initiatives have been taken to reduce greenhouse gas (GHG) emissions, both comprehensively and in specific sectors. While shipping-related emissions make up a relatively small amount of the total global emissions (approximately $2.89 \%$ ), these emissions could grow between 90-130\% over 2008 values by 2050 on a business-asusual track (International Maritime Organization, 2020). With an internal mandate and a designation by the Kyoto Protocol as the competent forum for climate change issues related to international shipping, the International Maritime Organization (IMO) has come under significant pressure to act on emissions reductions, particularly from ambitious climate actors like the EU.
In April 2018, at the 72nd Meeting of the Marine Environment Protection Committee (MEPC), the IMO adopted its Initial Strategy on Reducing GHG Emissions in Shipping (hereafter Initial Strategy) which lays down the first steps for the decarbonization of the sector. While the Initial Strategy establishes targets for reductions in carbon intensity and GHG emissions, it remains a non-binding political declaration.

In a communiqué, the European Commission (hereafter Commission) heralded the Initial Strategy as a "significant step forward in global efforts to tackle climate change" and noted that "the EU and its member states played an instrumental role in brokering and securing this deal with our international partners" (European Commission, 2018a). The statement suggests that, at least in the eyes of the Commission, the EU achieved its goal at the IMO thanks to its active role in the 
negotiations. However, two factors potentially contradict this self-assessment. First, the EU itself is not a fullyfledged member of the IMO, nor does it have clear-cut competence over GHG emissions from shipping (Cinelli, 2019). Therefore, it was relatively constricted in the negotiations because of its legal status and competences. Second, research by Corbett et al. (2020) suggests that the successful outcome in the negotiations can largely be attributed to the entrepreneurship of the Marshall Islands. These two factors call into question whether the EU's "success" in the IMO was the result of the role played by the EU, or rather of the EU benefitting from a fortuitous negotiating context.

This article therefore answers the following research question: How was the EU able to achieve its objective in the IMO Initial Strategy of 2018? Using the explainingoutcome variant of process-tracing, we examine the factors at both the EU and international levels that led to the EU achieving its objective of action in the IMO on GHG emissions reduction. Note that due to the EU's lack of membership in the IMO and the unclear competences on GHG emissions in shipping, the EU in this article refers to EU institutions or EU member states acting on the basis of an established Union objective or position. This article unpacks the complexity surrounding emission reductions in international shipping, which is particularly timely as shipping emission reduction is included in the Commission's 2019 European Green Deal.

In that regard, a notable provision of the European Green Deal is the 2021 legislative proposal by the Commission to revise the EU Emissions Trading System (ETS) and to include shipping emissions in the ETS (European Commission, 2021). Whereas the ETS will undoubtedly play an important role for the achievement of the European Green Deal's target of climate neutrality by 2050 , it seemingly also carries implications for EU leadership at the global level (see Dupont \& Torney, 2021). The Commission proposal to amend the ETS directive notes the insufficient progress in the IMO on GHG emissions reduction and that "EU action can also inspire and pave the way for the development of market based measures at global level, e.g., as regards the maritime transport within IMO" (European Commission, 2021, p. 8). The Commission proposal thus seems to be an attempt to drive decarbonization across the sector, both inside and outside the EU. Moreover, the proposed ETS reform not only significantly precipitates the decarbonization timeline established by the Initial Strategy but also could conflict with the IMO's propensity for global-level action. The further implementation of the European Green Deal via a reform of the ETS is thus expected to create even more turbulence, or "interactions of events or demands that are highly variable, inconsistent, unexpected, or unpredictable," at the international level (Ansell et al., 2016, p. 3). Therefore, an understanding of how the EU reached its objective with the Initial Strategy can help us frame the challenges and opportunities facing the European Green Deal's attempts not only to fit sectors like shipping within its climate goals but also to drive change around the world.

The article is structured as follows. The following three sections discuss the EU as an international (climate) actor, its role within the IMO and its climate diplomacy for shipping. Next, we provide an overview of the IMO Initial Strategy negotiations. Then, we present our analytical framework and methodological approach for examining EU goal achievement in this context. Following that, we break down the different elements of the causal mechanism. We then frame our findings within the current European Green Deal dynamic, notably the proposed inclusion of shipping in the ETS. Finally, we conclude and place our findings within the literature.

\section{The EU as an International (Climate) Actor}

Although the EU's participation in international organisations and other international institutional frameworks is often hindered by external and internal legal constraints (respectively related to the EU's status and competence distribution) and by divergences in member states' preferences, the EU has developed working methods allowing it to be recognized as an actor in international organizations (Wessel \& Odermatt, 2019). There is a rich literature on how the EU acts in international institutions, focusing on its actorness (Drieskens, 2017), performance (Jørgensen et al., 2011), or the EU's ultimate effectiveness, impact, or influence. Although research on the latter dimension has mostly assessed the EU's effectiveness by comparing the EU's initial position to the outcome of the international negotiations (Blavoukos \& Bourantonis, 2017; da Conceição-Heldt \& Meunier, 2014; Van Willigen \& Kleistra, 2013), scholarship increasingly takes into account what the EU did to achieve its predetermined goals (Groen, 2019; Oberthür \& Groen, 2015). Indeed, a fine-tuned assessment of the EU's goal achievement in international negotiations requires determining the extent to which the correspondence between the objective of the EU and the outcome of the international negotiations can be attributed to the EU's purposive action (Schunz, 2021).

Since the early 1990s, the EU has established itself as an international actor with leadership ambitions on environmental matters (Adelle et al., 2018; Delreux, 2011)particularly in the field of climate change (Oberthür \& Dupont, 2021; Parker et al., 2017). While the EU has long sought to lead by example with ambitious climate targets, the EU in recent years has employed a bridge-building approach to work with like-minded progressive allies to achieve consensus-based outcomes at the international level (Bäckstrand \& Elgström, 2013). The EU solidified its role as a climate "leadiator" with its successful climate diplomacy in the negotiations leading to the Paris Agreement in 2015 (Oberthür, 2016). This leadership has notably taken place in negotiations within the United Nations Framework Convention 
on Climate Change (UNFCCC). Additionally, the EU has sought to extend its leadership beyond the UNFCCCmultilaterally in other international fora, bilaterally via agreements, support and conditionality, and unilaterally.

\section{The EU at the IMO}

The EU's ability to formally participate in an international organization depends not only on its legal status (e.g., member or observer) but also the relevant competences in play (Wessel \& Odermatt, 2019). While it has long argued for full membership, the EU remains an ad-hoc observer at the IMO. Though the Commission maintains an accredited representation (Cinelli, 2019), EU member states are accustomed to acting individually in IMO negotiations (Gulbrandsen, 2013). Compared to other environmental issues, the EU's legal competence on GHG emissions in shipping is much murkier. The Commission has argued that as GHG emissions in shipping fall under climate change, the Union has some competence over such issues. However, this competence has thus far remained unexploited within the IMO. Nonetheless, member states usually coordinate their positions for IMO negotiations. Coordination is often difficult due to significant mismatch in the dynamic of large EU member states (e.g., France and Germany) versus smaller member states with strong shipping interests and therefore influence in the IMO (e.g., Cyprus, Greece, and Malta). The EU's position is usually hashed out in the Shipping Working Party of the Transportation Council configuration. EU member states usually speak in their national capacity as IMO members, with the Council Presidency seeking to speak first if possible to present the coordinated EU position (Gulbrandsen, 2013).

The literature on the EU in the IMO, particularly on environmental issues, is relatively sparse. However, scholars have examined the EU's potential to shape the IMO via its own internal legislation. For instance, a study by van Leeuwen and Kern (2013) finds that the EU has become an important player in IMO environmental policies, thanks to its ability to develop binding and enforceable policies on ships based in and traveling to the Union. As such, it can threaten the IMO with unilateral legislation. For instance, following the shipwreck of the tanker Erika off the coast of Brittany in 1999 and subsequent 10,000 tons oil spill, the EU threatened its own action on mandating double hulls for tankers. This prompted the IMO to hasten its existing schedule for the phasing out of single-hull tankers. After another accident-the running aground of the tanker Prestige and over 60,000 tons oil spill in 2002-the EU found the new IMO timeline insufficient and implemented its own shorter horizon in July 2003. The IMO adopted the text of the EU legislation at the international level several months later. Moreover, the pattern has extended to other areas. In 2015, the EU adopted the MRV Regulation (Monitoring, Reporting and Verification) to track the fuel consumption of ships docking in its ports. Poulsen et al. (2021) note that the IMO then adopted its own global fuel data collection system in 2016 as a response to the MRV. This fits with larger work on the EU's ability to sets standards at the international level via internal legislation, which Bradford (2020) refers to as the "Brussels Effect." On several occasions, the EU, via unilateral action has served as a source of turbulence at the IMO by disrupting the status quo.

The EU had been in favour of an agreement in the IMO to regulate shipping GHG emissions since at least 2003, adopting Council conclusions to that effect (Council of the European Union, 2003). However, different EU actors remained sceptical of the possibility of the IMO acting to address emissions. A Council document from 2012 noted "it should also be clear that not much progress can be expected in IMO... to reduce maritime GHG emissions" (Council of the European Union, 2012 , p. 17). Nonetheless, the Commission, through its observer status, continued to work to increase support for GHG emission reduction in the IMO, including by sponsoring a pilot program designed to build capacity for GHG emission reduction in shipping in key developing regions (European Commission, 2018b). As for unilateral action, in 2013, the Commission proposed a tiered strategy for reducing international shipping emissions (European Commission, 2013). The first part of the strategy, eventually adopted as the MRV Regulation in 2015, was seen as a means of encouraging IMO action while eventually building an emissions reduction scheme if the IMO were not to act (Martinez Romera, 2017). Nonetheless, as for EU climate action in the IMO, the status quo of generalized coordination accompanied by member state latitude has persisted. In that sense, the EU actors at the IMO have been relatively insulated from internal EU turbulence, which has been defined by a push among some actors, notably the European Parliament, for more ambition in decarbonizing international shipping.

\section{Climate Change at the IMO and the Negotiations on the Initial Strategy}

Questions related to climate change at the IMO are handled via its MEPC. The MEPC meets twice yearly and has the authority to adopt regulations related to "the prevention and control of pollution from ships" (Amendment to the Convention on the International Maritime Organization, 1975). The MEPC acts by majority vote, though consensus is the norm. The majority vote creates a negotiation dynamic that is different from the UNFCCC in that texts can advance despite objections or reservations from particular parties (Hackmann, 2011; Hayer, 2016).

Climate-related action within the IMO has traditionally been a complicated issue for the following four reasons. First, the international nature of shipping makes the attribution of emissions relatively complex (Selin et al., 2021). Ships are often registered in a "flag of convenience" system, meaning ship owners are free to register their vessels in the country of their choosing (Lister et al., 
2015). Moreover, ships often travel between many different countries on a single voyage, making the calculation of emissions attributions rather complicated. Second, the IMO uses a "no more favourable treatment" scheme, where all vessels are treated equally (Doelle \& Chircop, 2019; Hackmann, 2011; Lister et al., 2015). There is no differentiation between developing and developed countries as there is in the UNFCCC. Third, the power dynamic in the IMO is such that countries with the largest ship registries maintain an outsized influence in the organization (Hayer, 2016; Martinez Romera, 2017). While each IMO member state has one vote, states with the largest registries traditionally have more clout in the decisionmaking process, as they are the most impacted by regulations and contribute most to the budget (calculated by tonnage registered; Hayer, 2016). Major ship registry states (notably Liberia, Marshall Islands, and Panamaoften considered small players outside the IMO) are influential in the IMO. Finally, NGOs and industry have a long history of exerting influence in the IMO and in its negotiation outcomes (Hackmann, 2011; Martinez Romera, 2017).

Despite this complexity, from 2011 to 2014, the MEPC took a series of decisions mandating increased efficiency standards for newly-constructed vessels and efficiency management plans for existing vessels (Joung et al., 2020). The aforementioned data collection system was agreed upon at MEPC 69 (2016) in order to track fuel consumption, as a first step towards emission reduction (Poulsen et al., 2021).

The momentum on climate action within the IMO shifted in 2015, with two main events: a surprise proposal from the Marshall Islands at MEPC 68 in May; followed by the adoption of the Paris Agreement at the 21st Conference of the Parties (COP 21) of the UNFCCC in December. The Marshall Islands, the third largest shipping registry in the world, had until that point been represented at the IMO by shipping industry officials, and it had embraced an industry-friendly position on climate action (Corbett et al., 2020). However, at MEPC 68, Foreign Minister Tony de Brum presented a "Fair Share" proposal calling on shipping to do its part to work towards mitigating global temperature increase, citing the perilous future for his own country if no action were taken (Corbett et al., 2020; Selin et al., 2021).

While the proposal was not adopted, the Marshall Islands' change in representation and position opened a new dynamic in the IMO in favour of climate action (Corbett et al., 2020). Furthermore, the Paris Agreement increased momentum for climate action amongst IMO member states and industry (Corbett et al., 2020; Hayer, 2016; Selin et al., 2021). Over the next years, a majority of IMO member states (including bigger geopolitical players like China), industry, and the IMO secretariat moved towards an agreement (although with varying levels of ambition).

At MEPC 70 in October 2016, IMO member states agreed to a roadmap for adopting a GHG emissions reduction strategy within two years. An Intersessional working group on the reduction of GHG emissions from ships (ISWG-GHG) met three times outside of the normal MEPC meetings in order to draft the strategy. The Initial Strategy was adopted at the MEPC 72 in April 2018. It calls for: (1) a review of ship efficiency standards for new ships with the goal of reducing carbon intensity; (2) a reduction of carbon intensity of international ships by at least $40 \%$ by 2030 , with efforts towards $70 \%$ by 2050 (compared to 2008 levels); and (3) a peak in GHG emissions from international shipping as quickly as possible and a reduction of GHG emissions in 2050 by at least $50 \%$, while working towards phasing emissions out in a way consistent with the Paris Agreement temperature goals. It is at its core a political declaration and as such is nonbinding (Doelle \& Chircop, 2019). The Initial Strategy is to be revised in 2023 .

\section{Understanding Goal Achievement: Analytical Framework and Method}

EU goal achievement in international negotiations has traditionally been understood as the extent to which predetermined objectives (input) are present in the final negotiation outcome (output; Blavoukos \& Bourantonis, 2017; da Conceição-Heldt \& Meunier, 2014; Van Willigen \& Kleistra, 2013). Yet, it has also been acknowledged that goal achievement is affected by the EU engagement in the negotiations (process), and particularly the degree to which the EU's diplomatic activities fit with the international constellation of power and interests (Groen, 2019; Oberthür \& Groen, 2015). Indeed, the process element is key as well, as it links the EU's initial objective to the outcome and clarifies the extent to which the EU has (co-)shaped the negotiation outcome. In this case, the EU maintained an overarching objective to seek action within the IMO on GHG emissions reduction from shipping. However, it developed a specific negotiation position prior to MEPC 72. This position reflects the evolution and operationalisation of the aforementioned, longsought EU policy objective on reaching an agreement in the IMO on GHG emissions reduction from shipping.

In order to better understand the EU's contribution to correspondence between its objective and the outcome of the Initial Strategy negotiations, we employ the explaining-outcome variant of process-tracing, which allows us to develop a case-specific explanation of the factors that led to the outcome (i.e., the EU achieving its objective) and the cause(s) that triggered it all (Beach \& Pedersen, 2019). We craft a causal mechanism-the process linking the cause to the outcome-in working backwards, looking for minimally sufficient explanations of the elements of the mechanism (Beach \& Pedersen, 2019). While this causal mechanism works backward from the EU achieving its objective (outcome), we are not testing goal achievement theory as such, instead exploring how the EU achieved its outcome in this particular case. 
We triangulate data collected from official documents (EU, EU member states, related coalition partners, and IMO) and 13 semi-structured interviews. We interviewed 10 officials from the EU (Commission and Council Secretariat) and its member states involved in the negotiations and/or the preparation of the EU position (see Table 1 in the Supplementary File). Additionally, we interviewed three "non-EU" sources involved in the negotiations to check findings from our EU-centric sample. The interview transcriptions and documents were coded manually in NVivo.

\section{Causal Mechanism Leading to the EU Achieving its Overarching Objective}

In line with the explaining-outcome variant of processtracing, we created the following causal mechanism (Figure 1). This section first discusses the causes, then the five steps in the causal mechanism which lead to the outcome.

\subsection{Causes}

The explaining-outcome variant of process-tracing permits us to look more holistically at the underlying factors without which the EU would not have achieved its objective. A first cause is the EU's overarching objective to handle GHG emissions reduction in shipping in the IMO. However, that alone was insufficient, otherwise an agreement would likely have been reached earlier, as the EU had already been stating that preference since 2003. Thus, we look elsewhere to see what factors contributed to the EU reaching its objective. Two additional causes stand out: a motivated entrepreneur with similar objectives, and international momentum. These causes also served as sources of turbulence in the negotiations, as they up-ended the status quo within the IMO, shifting the parameters of the discussion on GHG emissions reduction in the IMO. In that sense, they served as part of the "tipping point" of ushering in a different dynamic of climate action (Dobbs et al., 2021).

\subsubsection{Cause 1: EU Seeks Action on GHG Emissions} Reduction in IMO

A logical first cause is the EU having an overarching objective to regulate GHG emissions from shipping through the IMO, which dates back to 2003. Moreover, an impact assessment on EU unilateral action in shipping in 2013 stated "strong preference for a global approach led by the IMO" (European Commission, 2013, p. 4). Furthermore, support for negotiations in the IMO was also reflected in Conclusions from the Environment Council and the Foreign Affairs Council (Council of the European Union, 2015, 2016). Hence, the EU had a longstanding and broadly-shared objective of pursuing action in the IMO to regulate shipping emissions. Such action required an agreement in MEPC.

\subsubsection{Cause 2: Motivated Entrepreneur (Marshall Islands) with Similar Objectives to EU}

The remarkable turnabout by the Marshall Islands in 2015 constituted a significant shift in climate governance on shipping. A state that had previously been a prominent defender of the shipping industry as a flag registry radically changed position at MEPC 68. Its proposal significantly altered the general attitude amongst the different stakeholders - from industry to member states-within the IMO on climate change (Interviews 1, 3, 5, 7; Corbett et al., 2020). This should be framed in the larger push of the Marshall Islands on climate change. That same year, the Marshall Islands played a prominent role in the creation of the High Ambition Coalition in the UNFCCC, which helped deliver the Paris Agreement (Brun, 2016).

\subsubsection{Cause 3: Momentum Builds for Action in the IMO}

The increasing momentum for climate action in the IMO also stands out as part of the triggering of the mechanism. Externally, the road to COP 21 and the subsequent Paris Agreement in 2015 kickstarted new political momentum for action in the IMO, establishing
Causes

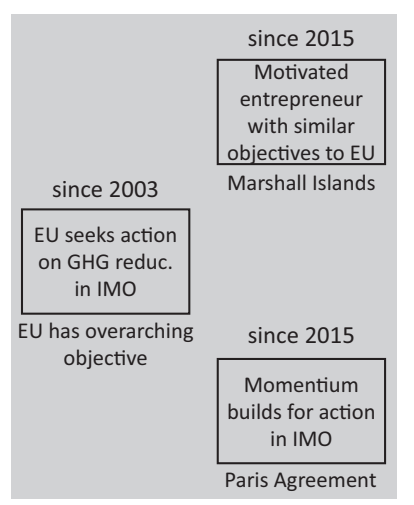

Causal Mechanism

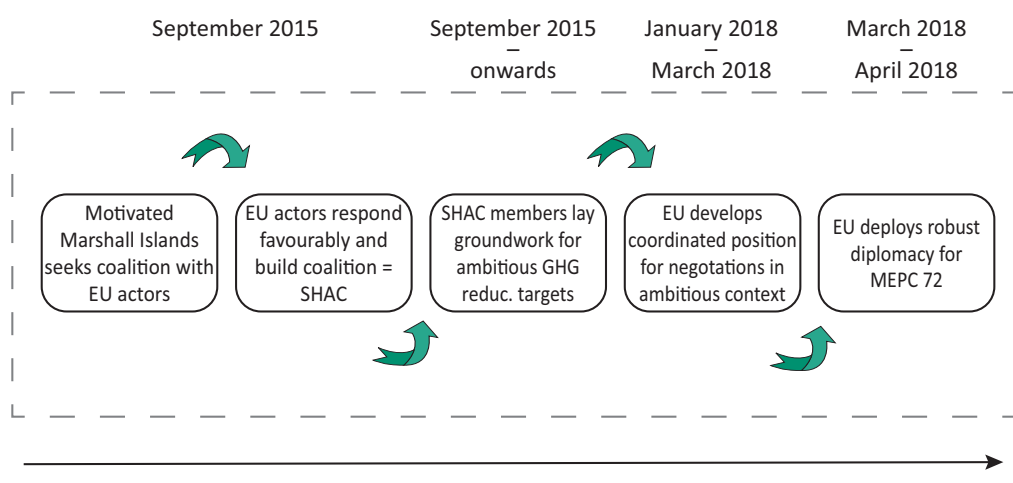

Outcome

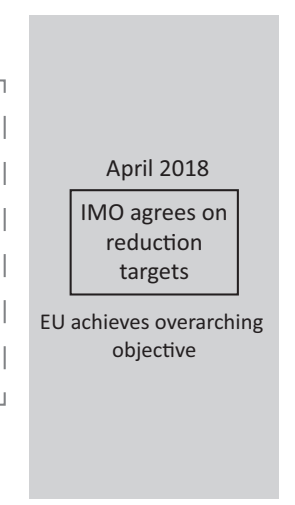

Figure 1. Causal mechanism. 
a level of ambition to which the international community and, by extension, the IMO were accountable (Interviews 1, 3, 4, 5, 6, 8, 10, 13). IMO member states and the IMO as a whole were pushed to act in way consistent with the commitments and temperature targets made in Paris (Interviews 3, 4, 5, 13; Council of the European Union, 2018; International Maritime Organization, 2018a). The Paris Agreement inserted political pressure into the IMO to take action. Additionally, advancements in technology in the shipping sector and a number of pilot projects demonstrated that energy efficiency measures often made good sense economically (Interviews 8, 13).

Together, these three causes created an opening for action in the IMO on GHG emissions reduction. In that sense, they triggered the causal mechanism that eventually led to the Initial Strategy and the EU's successful outcome. The EU's overarching objective is only one cause of the goal-achievement mechanism. However, it was the favourable external circumstances-those situational circumstances exogenic to the EU's objective (Oberthür \& Groen, 2018)-that were necessary for the mechanism to be triggered.

\subsection{The Mechanism in Action}

\subsubsection{Step 1: Marshall Islands Seeks Coalition with EU Actors}

In September 2015, the Marshall Islands, with the assistance of several scientific advisors, organized a dinner on the side-line of an ISWG-GHG meeting with representatives from Belgium, France, Germany, the Netherlands, and the Commission to discuss potential collaborations (Interviews 1, 5, 7; Corbett et al., 2020). The Marshall Islands stressed that it and other Pacific states wished to contribute substantively on climate action in the IMO, but they lacked the necessary resources to send delegations to the IMO meetings scheduled throughout the year in London and make proposals. It therefore requested support from the European actors to facilitate this (Interviews 3, 5).

\subsubsection{Step 2: EU Actors Respond Favourably and Engage in Coalition}

Those EU actors solicited at the dinner responded favourably, and a collaborative network was formed. The group met regularly, both on the side-lines of IMO meetings and in other contexts. The ambiguity of the shipping GHG competences and the strong state-level tradition in the IMO seem to have given EU actors the flexibility to join this coalition. They could agree to collaborate without needing to go through official EU coordination channels. Moreover, several EU and member state officials noted a preference amongst certain member states to work outside of the EU in the context of the new coalition (Interviews 4, 5, 9, 11). Two years later, at a meeting in the South Pacific, a Marshallese official, who had also been involved in UNFCCC negotiations, introduced the network as the "Shipping High Ambition Coalition" (SHAC; no direct connection to the "High Ambition Coalition" beyond that), and the name stuck (Interview 5). The original EU actors in SHAC were later joined by the other EU member states, with the exception of Cyprus, Greece, and Malta. Coordination mainly occurred between the aforementioned original EU actors alongside the Pacific states.

6.2.3. Step 3: SHAC Coalition Members Lay Groundwork for Ambitious GHG Emissions Reduction Targets

Shortly after its inception, SHAC worked to determine what a "fair share" contribution from shipping to GHG emissions reductions would look like and how it could be put into place (Interview 5). Within the IMO, SHAC coordinated the submission of proposals and GHG emissions reduction strategies (Interviews 3, 5). In that sense, SHAC members often served as a check on the level of ambition in the IMO, stressing the existential nature of the climate threat to SHAC's island members. As an official noted, SHAC "in a way kept the whole negotiation honest, because it meant that there were those in the room that would fundamentally look at what was proposed and say 'That's not good enough.'” (Interview 13). Outside the IMO, SHAC sought to bring more political attention to the issue of emissions from shipping. The technical, non-climate background of most delegates in the IMO often led to a difference between a state's position on climate in the IMO and other climate fora like the UNFCCC (Interviews 5, 7, 9, 11). Along those lines, the SHAC coordinated presentations on the urgency of action within the IMO at different UNFCCC Conference of the Parties meetings. The most prominent example of SHAC's efforts was the "Tony de Brum Declaration," presented at the One Planet Summit, a high-level international meeting organized by France for the second anniversary of the Paris Agreement in 2017. The declaration, drafted by France and coordinated in the SHAC, stressed the urgency of action within the IMO in a way consistent with the Paris Agreement. One EU member state official remarked, "The idea was to go above the experts who come to the IMO and go to the political level above" (Interview 5). SHAC members also coordinated outreach efforts, via the members' own contacts and diplomatic networks, during their regular meetings (Interviews 3, 5, 6, 7, 11). Such action was mostly concentrated on convincing others of the urgency of action in the IMO.

6.2.4. Step 4: EU Develops Coordinated Position in Negotiations Within Broader Ambitious Context

As SHAC worked to raise the urgency of action within the IMO, the EU intensified its coordination for MEPC 72 in early 2018. The member states and the Commission 
coordinated an EU position in the Shipping Working Party. The Council Presidency, Bulgaria, but here represented by its predecessor Estonia, needed to generate consensus among not only the ambitious SHAC EU member states but also the traditionally shipping-heavy Mediterranean states (Interviews 4, 9, 11). The Shipping Working Party ultimately took four meetings (instead of the usual one) to draft a compromise coordination document for the negotiations, agreed upon two weeks before MEPC 72. The position, which included ambitious targets with relatively open-ended language, "gave something for the ambitious countries and something for the other countries that weren't so ambitious" (Interview 11).

The existence of SHAC seems to have at least indirectly shaped internal EU coordination within the Shipping Working Party, as the EU member states in SHAC reflected SHAC's ambition in the Shipping Working Party. Additionally, EU institutional actors were regularly informed of and included in SHAC's meetings. An EU member state official suggested that SHAC influenced the final EU position, saying "we went to the IMO negotiations with the higher ambition than we would have otherwise" (Interview 9).

\subsubsection{Step 5: The EU Deploys Robust Diplomacy for MEPC 72}

Following the coordinated position, the EU deployed a series of diplomatic activities related to the negotiations. The activity can be broken down into three categories: (1) bilateral outreach in the weeks leading up to the negotiations; (2) persuasion and discussion during the negotiations; and (3) exerting EU institutional pressure during the negotiations. The first two elements were coordinated by Estonia (on behalf of the Council Presidency), while the Commission and European Parliament delegations exerted pressure during the negotiations. Although they were working towards the same goal, the actions were largely undertaken independently of each other.

First, once a position was agreed upon, the Council Presidency worked to extend EU leverage using SHAC and the diplomatic and historic ties between EU member states and third states (Interview 9). They also engaged with the IMO secretariat, who was in favour of an agreement (Interviews 1,9) and who, along with the ISWG-GHG chair, facilitated the process in such a way that left an opening for input on ambitious action (Interviews 4, 12, 13).

Second, as for persuasion, a particularly interesting innovation on the part of the Council Presidency was the inclusion of a climate negotiator in its delegation, as opposed to the typical transport-specific delegation (Interviews 4, 9, 11, 12). The negotiator informally engaged with delegates from smaller states unfamiliar with climate governance and explained the larger principles governing climate action in the Paris Agreement and the urgency of action, including at several infor- mal meetings organized by the chair of the ISWG-GHG (Interviews 4, 9, 11).

Third, concerning EU institutional pressure, during the final negotiations, the European Commissioner for Mobility and Transport, Violeta Bulc, was present, as was a delegation of the European Parliament. Commissioner Bulc met one-on-one with different states and "put the case to them so that they understood why it was important" while the delegation of the European Parliament met with different stakeholders, "playing the bad cop," sending the message to other IMO member states that the EU would take unilateral regulatory action in the field of international shipping: "Well, if you don't do something, then we will" (Interview 8). Together, their presence underscored the political appetite for ambitious action in the EU, notably among the two institutional actors that would otherwise be excluded via exclusive member state coordination. It also gave the impression of a relatively united EU front. According to an EU member state official, "the EU was kind of united at the IMO, and that actually helped a lot in terms of the final agreement as well" (Interview 9).

Through this diplomacy, the EU was able to drive the negotiations in a way that allowed it to achieve its objective of reaching an agreement at the IMO. An official from a non-EU country noted: "I would say the European bloc was clearly influential in having a strategy which was meaningful when it comes to creating a clear new direction for shipping" (Interview 12).

\subsection{Outcome: EU Achieves Overarching Objective (yet not the Precise Targets)}

With the final agreement, the EU achieved its objective of an agreement being reached within the IMO. However, while action on $\mathrm{GHG}$ emissions reduction in the IMO was attained by the EU, the Union's specific negotiation position was only partially reflected in the final agreement. First, whereas the EU supported "the objective of $70 \%$ and pursue efforts towards $100 \%$ reduction of GHG emissions from international shipping by 2050 (compared to 2008 levels)" (Council of the European Union, 2018, p. 14), the IMO members committed themselves to "to reduce the total annual GHG emissions by at least $50 \%$ by 2050" (International Maritime Organization, 2018b, p. 5) in the Initial Strategy. Second, although the $\mathrm{EU}$ preferred to "reduce $\mathrm{CO} 2$ emissions per tkm as an average across international shipping by $50 \%$ " and to "pursue efforts towards $70 \%$ by 2030 relative to 2008 levels" (Council of the European Union, 2018, p. 14), the Initial Strategy mentions "to reduce $\mathrm{CO} 2$ emissions per transport work, as an average across international shipping, by at least $40 \%$ by 2030" (International Maritime Organization, 2018b, p. 5). As the EU communiqué noted: "While the EU had sought a higher level of ambition, this is a good starting point" (European Commission, 2018a). Thus, EU goal achievement must be nuanced in that the overall goal of an agreement was met, but it did not fit 
entirely with the eventual precise ambitious targets the EU had hoped for.

\section{Implications for the European Green Deal}

Our case study allows us to make several important observations about the underlying dynamics of climate action at the IMO, which will likely affect how the EU could achieve the objectives of the European Green Deal in the IMO. In keeping with the theme of the thematic issue, we make three main reflections which are framed within several dimensions of the concept of turbulence.

A first reflection is that the proposed inclusion of shipping in ETS is a more aggressive move than anything the EU undertook in the Initial Strategy negotiations. It can be construed as a unilateral threat to drive progress in the IMO. However, unilateral threats did not appear to play an irrefutable role in the EU achieving its objective at MEPC 72, though several implicit references came up. Nonetheless, the EU does have a successful track record of using threats to achieve its objectives at the IMO (Poulsen et al., 2021; van Leeuwen \& Kern, 2013). Thus, it is possible that the inclusion of shipping in the ETS could spur international action, as evidenced by the shipping industry's proposal of $\$ 5$ billion in research funding for decarbonization following the European Green Deal announcement (Psaraftis \& Kontovas, 2020). However, several interview respondents feared that unilateral action would affect the potential for future action on climate in the IMO-an opinion shared by the IMO secretary general to the presidents of the EU institutions in late 2016 (International Maritime Organization, 2017). At the same time, the urgency of the climate crisis has become all the more apparent, and the IMO has done relatively little beyond the Initial Strategy to address the impact of shipping on climate change (Healy, 2020). In that sense, unilateral action could serve as a source of turbulence in the IMO.

A second reflection is that the EU seeking action in the IMO on GHG emissions reduction, as it hopes to do with the European Green Deal, was only one of the causes that triggered the mechanism. If the EU wants to bring about more ambitious action in the IMO, based on the Initial Strategy negotiations, it would be wellserved to find partners with similar objectives and influence in the IMO and it needs international momentum. Although climate action in shipping continues to gain traction since the adoption of the Initial Strategynotably with the Niulakita Declaration, discussed at the 2019 G7 Biarritz Summit and calling for further GHG emissions reduction in international shipping-the push for recovery after the Covid-19 pandemic and ensuing environmental turbulence could impact the pressure placed on the IMO to take more forceful action on climate.

Finally, the EU's status at the IMO and the unclear competences on GHG emissions in shipping paradoxically also seemed to contribute to the achieving of its objective at the IMO. It allowed more ambitious EU member states to act outside the EU, notably in SHAC. The consensus-based EU position gave ambitious EU member states room to manoeuvre, while the more shipping heavyweight member states were comfortable with the open-endedness of the position. If adopted, the proposal to include shipping in ETS would seemingly strengthen the EU's competence on GHG emissions from shipping, which could reduce the leeway for EU member states in the IMO (Interviews 5, 8). This dynamic could infuse what Dobbs et al. (2021) refer to as horizontal turbulence into the EU approach to the IMO and potentially impact EU member state coalition building with other IMO actors.

Overall, the European Green Deal charts a new course for incorporating EU climate ambition into shipping. While the final scope of the revised ETS remains to be seen, it is likely to represent a significant departure from the past ways in which the EU has successfully pursued its objectives at the IMO. In that sense, the European Green Deal looks to be a source of turbulence both within the EU and in the IMO.

\section{Discussion and Conclusion}

This article analysed the factors and the mechanism that led to the EU achieving its objective of reaching an international deal on GHG emissions reduction from shipping with the IMO's Initial Strategy. While the EU had long sought action on emission reductions in the IMO, the causal mechanism was not triggered until 2015, with a radical change of position by the Marshall Islands and an increase in momentum for climate action in the IMO. Collectively, these three causes enabled the EU to achieve its overarching objective of reaching an IMO agreement on GHG emissions from international shipping. This case therefore shows that it was not simply EU activity that permitted the EU to achieve its objective. Instead, here, the favourable circumstances were important causes without which the mechanism would not have been triggered.

These findings have two notable implications for the literature. First, with respect to the study of the EU within international organizations, they provide an example of the EU's ability to achieve its objective even in situations where it is not a full-fledged actor. The EU's loose coordination structure actually played an important role in the causal mechanism. In a sense, it helped facilitate the EU's ultimate goal achievement in that it gave the ambitious member states the space to manoeuvre outside of official EU coordination and eventually fed back into the EU position. This could have implications for our understanding of the EU's role in a variety of fields in which it is not a completely established actor or in international institutions where the EU is not a full member or party. However, as we have engaged in the outcomeexplanation variant of process-tracing, caution should be used in extrapolating our findings beyond this specific case, where alternative explanatory factors could be at 
play. To that end, future research on EU goal achievement in other areas where the Union is not an established actor is needed.

Second, our case study somewhat challenges the EU's role as a climate leader outside of the UNFCCC. It calls into question the extent that this leadership extended into the IMO. The EU seemed to have abandoned hope of an agreement in the IMO in the early 2010s. Moreover, it was the Marshall Islands that approached the EU about a coalition. Together, these steps are more indicative of a reactive actor. While the EU may have indeed had climate leadership ambitions for action on climate change in shipping, it was actually relatively restrained by not only its membership status and limited competences but also by the unique dynamic of the IMO. Along those lines, there is a pressing need for more research in not only the IMO but also other non-UNFCCC fora handling climate change. As our findings have shown, these oftenforgotten fora remain important pieces of the global climate governance puzzle.

\section{Acknowledgments}

This work was supported by the Fonds de la Recherche Scientifique (FNRS) under Grant T.0064.19. The authors wish to thank the thematic issue editors, participants of the Workshop “Governing the EU's Climate and Energy Transition in Turbulent Times" at the ECPR Joint Sessions (April 2020) and the GOVTRAN Workshop "Climate Governance and the EGD in Turbulent Times" (November 2020), and three anonymous peer reviewers.

\section{Conflict of Interests}

The authors declare no conflict of interests.

\section{Supplementary Material}

Supplementary material for this article is available online in the format provided by the author (unedited).

\section{References}

Adelle, C., Biedenkopf, K., \& Torney, D. (Eds.). (2018). European Union external environmental policy: Rules, regulation and governance beyond borders. Palgrave Macmillan.

Amendment to the Convention on the International Maritime Organization (IMO), § Part IX: Marine Environment Protection Committee, 1975.

Ansell, C. K., Trondal, J., \& Øgård, M. (2016). Turbulent governance. In C. K. Ansell, J. Trondal, \& M. Øgård (Eds.), Governance in turbulent times (pp. 1-33). Oxford University Press.

Bäckstrand, K., \& Elgström, O. (2013). The EU's role in climate change negotiations: From leader to "leadiator." Journal of European Public Policy, 20(10), 1369-1386.
Beach, D., \& Pedersen, R. B. (2019). Process-tracing methods: Foundations and guidelines ( 2 nd ed.). University of Michigan Press.

Blavoukos, S., \& Bourantonis, D. (Eds.). (2017). The EU in UN politics: Actors, processes and performances. Palgrave Macmillan.

Bradford, A. (2020). The Brussels effect: How the European Union rules the world. Oxford University Press.

Brun, A. (2016). Conference diplomacy: The making of the Paris Agreement. Politics and Governance, 4(3), 115-123.

Cinelli, C. (2019). Law of the sea framework: Is EU engagement a sine qua non for influence? In R. A. Wessel \& J. Odermatt (Eds.), Research handbook on the European Union and international organizations (pp. 462-482). Edward Elgar.

Corbett, J., Ruwet, M., Xu, Y.-C., \& Weller, P. (2020). Climate governance, policy entrepreneurs and small states: Explaining policy change at the International Maritime Organisation. Environmental Politics, 29(5), $1-20$.

Council of the European Union. (2003). A European Union strategy to reduce atmospheric emissions from seagoing ships: Council conclusions (16369/2003).

Council of the European Union. (2012). Working document: Preparation of IMO/MEPC 63 (London, 27 February-2 March 2012) (W. Doc. 2012/4 REV 1).

Council of the European Union. (2015). Council conclusions on the preparations for the 21st session of the Conference of the Parties (COP 21) to the United Nations Framework Convention on Climate Change (UNFCCC) and the 11th session of the Meeting of the Parties to the Kyoto Protocol (CMP 11) (Paris, 30 November-11 December 2015) (12165/15).

Council of the European Union. (2016). European climate diplomacy after COP21: Council conclusions (6061/16).

Council of the European Union. (2018). 72nd session of the IMO Marine Environment Protection Committee (London, 9-13 April 2018): Non-paper from the Commission drafted to facilitate EU co-ordination in relation to agenda item 7 on the reduction of GHG emissions from ships.

da Conceição-Heldt, E., \& Meunier, S. (2014). Speaking with a single voice: Internal cohesiveness and external effectiveness of the EU in global governance. Journal of European Public Policy, 21(7), 961-979.

Delreux, T. (2011). The EU as international environmental negotiator. Ashgate.

Dobbs, M., Gravey, V., \& Petetin, L. (2021). Driving the European Green Deal in turbulent times. Politics and Governance, 9(3), 316-326.

Doelle, M., \& Chircop, A. (2019). Decarbonizing international shipping: An appraisal of the IMO's Initial Strategy. Review of European, Comparative \& International Environmental Law, 28(3), 268-277.

Drieskens, E. (2017). Golden or gilded jubilee? A research 
agenda for actorness. Journal of European Public Policy, 24(10), 1534-1546.

Dupont, C., \& Torney, D. (2021). European Union climate governance and the European Green Deal in turbulent times. Politics and Governance, 9(3), 312-315.

European Commission. (2013). Communication from the Commission to the European Parliament, the Council, the European economic and social committee and the committee of the regions: Integrating maritime transport emissions in the EU's greenhouse gas reduction policies (COM[2013] 479 final).

European Commission. (2018a, April 13). Commissioners Bulc and Arias Cañete welcome the IMO agreement on $\mathrm{CO} 2$ reductions in the maritime sector [Press release]. https://ec.europa.eu/transport/modes/ maritime/news/2018-04-13-imo-agreement-co2_en

European Commission. (2018b, September 27). EUfunded project supports efforts to reduce $\mathrm{CO} 2$ emissions from shipping [Press release]. https://ec. europa.eu/newsroom/intpa/items/635137/en

European Commission. (2021). Proposal for a directive of the European Parliament and of the council amending directive 2003/87/EC establishing a system for greenhouse gas emission allowance trading within the Union, decision (EU) 2015/1814 concerning the establishment and operation of a market stability reserve for the Union greenhouse gas emission trading scheme and Regulation (EU) 2015/757 (COM[2021] 551 final).

Groen, L. (2019). Explaining European Union effectiveness (goal achievement) in the Convention on Biological Diversity: The importance of diplomatic engagement. International Environmental Agreements: Politics, Law and Economics, 19(1), 69-87.

Gulbrandsen, C. (2013). Navigating from conflict to working arrangement: EU coordination in the International Maritime Organization. Journal of European Integration, 35(7), 749-765.

Hackmann, B. (2011). Analysis of the governance architecture to regulate $\mathrm{GHG}$ emissions from international shipping. International Environmental Agreements: Politics, Law and Economics, 12(1), 85-103.

Hayer, S. (2016). Decision-making processes of ICAO and IMO in respect of environmental regulations. European Parliament.

Healy, S. (2020). Grenhouse gas emissions from shipping: Waiting for concrete progress at IMO level. European Parliament.

International Maritime Organization. (2017, January 9). IMO Secretary-General speaks out against regional emission trading system [Press release]. https:// www.imo.org/en/MediaCentre/PressBriefings/ Pages/3-SG-emissions.aspx

International Maritime Organization. (2018a). Report of the Working Group on reduction of GHG emissions from ships (MEPC 72/WP.7).

International Maritime Organization. (2018b). Resolution MEPC.304(72) (adopted on 13 April 2018): Ini- tial IMO strategy on reduction of GHG emissions from ships.

International Maritime Organization. (2020). Fourth IMO GHG study.

Jørgensen, K., Oberthür, S., \& Shahin, J. (2011). Introduction: Assessing the EU's performance in international institutions-Conceptual framework and core findings. Journal of European Integration, 33(6), 599-620.

Joung, T.-H., Kang, S.-G., Lee, J.-K., \& Ahn, J. (2020). The IMO Initial Strategy for reducing greenhouse gas (GHG) emissions, and its follow-up actions towards 2050. Journal of International Maritime Safety, Environmental Affairs, and Shipping, 4(1), 1-7.

Lister, J., Poulsen, R. T., \& Ponte, S. (2015). Orchestrating transnational environmental governance in maritime shipping. Global Environmental Change, 34, 185-195.

Martinez Romera, B. (2017). Regime interaction and climate change: The case of international aviation and maritime transport. Routledge.

Oberthür, S. (2016). Where to go from Paris? The European Union in climate geopolitics. Global Affairs, 2(2), 119-130.

Oberthür, S., \& Dupont, C. (2021). The European Union's international climate leadership: Towards a grand climate strategy? Journal of European Public Policy, 28(7), 1095-1114.

Oberthür, S., \& Groen, L. (2015). The effectiveness dimension of the EU's performance in international institutions: Toward a more comprehensive assessment framework. JCMS: Journal of Common Market Studies, 53(6), 1319-1335.

Oberthür, S., \& Groen, L. (2018). Explaining goal achievement in international negotiations: The EU and the Paris Agreement on climate change. Journal of European Public Policy, 25(5), 708-727.

Parker, C., Karlsson, C., \& Hjerpe, M. (2017). Assessing the European Union's global climate change leadership: From Copenhagen to the Paris Agreement. Journal of European Integration, 39(2), 239-252.

Poulsen, R. T., Ponte, S., van Leeuwen, J., \& Rehmatulla, N. (2021). The potential and limits of environmental disclosure regulation: A global value chain perspective applied to tanker shipping. Global Environmental Politics, 21(2), 99-120.

Psaraftis, H. N., \& Kontovas, C. A. (2020). Influence and transparency at the IMO: The name of the game. Maritime Economics \& Logistics, 22(2), 151-172.

Schunz, S. (2021). Analysing the effectiveness of European Union external action. In S. Gstöhl \& S. Schunz (Eds.), The external action of the European Union: Concepts, approaches, theories (pp. 126-142). Palgrave Macmillan.

Selin, H., Zhang, Y., Dunn, R., Selin, N. E., \& Lau, A. K. $H$. (2021). Mitigation of CO2 emissions from international shipping through national allocation. Environmental Research Letters, 16(4). https://doi.org/ 
10.1088/1748-9326/abec02

van Leeuwen, J., \& Kern, K. (2013). The external dimension of European Union marine governance: Institutional interplay between the EU and the International Maritime Organization. Global Enivronmental Politics, 13(1), 69-87.

Van Willigen, N., \& Kleistra, Y. (2013). Evaluating diplo- macy. In K. E. Jørgensen \& K. V. Laatikainen (Eds.) Routledge handbook on the European Union and international institutions: Performance, policy, power (pp. 102-112). Routledge.

Wessel, R. A., \& Odermatt, J. (Eds.). (2019). Research handbook on the European Union and international organizations. Edward Elgar Publishing.

\section{About the Authors}

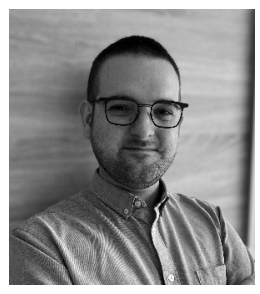

Joseph Earsom is a PhD researcher in political science at the University of Louvain (UCLouvain). His research interests include EU climate policy, climate diplomacy, international negotiations, and regime complexity. His doctoral research examines how the EU connects its diplomatic activity across the different multilateral fora dealing with climate change governance. Follow him on Twitter @EarsomJ.

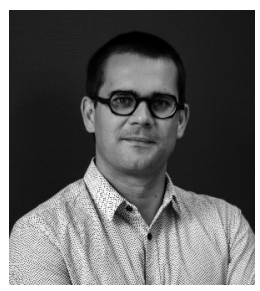

Tom Delreux is a professor of political science and EU politics at the University of Louvain (UCLouvain) and a visiting professor at the College of Europe. His research interests include the EU's external relations, EU environmental policy, EU institutions and international environmental politics. Follow him on Twitter @tomdelreux. 